\title{
Peluang dan tantangan aplikasi baut tulang mampu terdegradasi berbasis logam magnesium
}

\author{
A. Hermanto ${ }^{1,2}$, Y. Burhanudin 1 , I. Sukmana ${ }^{1 *}$ \\ ${ }^{1}$ Program Studi Magister Teknik Mesin, Fakultas Teknik, Universitas Lampung, Jl. Prof. Soemantri \\ Brojonegoro No. 1, Bandar Lampung 35143 \\ ${ }^{2}$ SMA Negeri 1 Seputih Agung, Jl. Raya Dono Arum Kecamatan Seputih Agung Kabupaten Lampung \\ Tengah, Lampung. \\ *Email: Irza.Sukmana@eng.unila.ac.id
}

\section{ARTICLE INFO}

Article history:

Received 01 June 2016

Accepted 10 August 2016.

Available online 30 December 2016

Keywords:

Bone screw

Magnesium

Casting

Degradable materials

\section{ABSTRACT}

This paper reviews the potential and challenges for the application of biodegradable bone screw materials. Currently, in the field of medical sciences and biomedical engineering devices, a non-degradable bone screw is the most acceptable concept to repair a bone fracture. However, with the new intervention and development of advanced materials, either in polymer-based or metallicbased, opens a possibility to use a degradable bone screw. Magnesium-based material is one of the most promising candidates for biodegradable bone screw application, which is the main focus of this paper. Casting technologies for producing magnesium alloys will also highlighted.

\section{PENDAHULUAN}

Patah (fraktur) tulang merupakan salah satu jenis kegagalan, disfungsi tulang atau trauma tulang yang dapat disebabkan oleh cacat bawaan, penyakit, maupun karena kecelakaan. Trauma tulang dapat juga dipicu oleh faktor usia, seperti terjadinya fraktur karena penuaan tulang (osteoporosis). Kasus fraktur tulang di Indonesia terus meningkat dari tahun ke tahun. Berdasarkan data penderita yang dirawat di Staf Medis Fungsional (SMF) Ilmu Bedah Rumah Sakit Umum DR. Soetomo Surabaya tahun 20012005 yang dirangkum oleh Reksoprawiro (2006), menunjukkan bahwa penderita fraktur tulang akibat kecelakaan lalu lintas sekitar 64,38\%. Dari data tersebut, angka kejadian fraktur pada mandibula (rahang bawah) dan maksila (rahang atas) menempati urutan terbanyak yaitu sebesar $29,85 \%$, fraktur zigoma (rangka wajah) $27,64 \%$ dan fraktur nasal (hidung) 12,66\%. Peningkatan yang sama juga terjadi di dunia, dimana patah tulang pangkal paha atau panggul (hip bone) di seluruh dunia mencapai angka 1,66 juta kasus di tahun 1990 dan diperkirakan terus meningkat hingga angka 6,26 juta kasus pada tahun 2050 (Doblare, 2004).

Dalam kedokteran ortopedi modern, salah satu strategi untuk penyembuhan kasus fraktur tulang adalah dengan memanfaatkan pelat penyangga berbahan logam tahan karat yang dibautkan langsung pada daerah sekitar tulang yang patah. Menurut Denkana et al. (2011), pelat penyangga tahan karat yang sering digunakan diantaranya dari bahan baja tahan karat, paduan titanium, dan platinum. Karena sifatnya yang bertujuan untuk memberi dukungan mekanis kepada tulang agar dapat bergerak dinamis, maka pelat penyangga ini dikenal sebagai pelat kompresi dinamis atau dynamic compression plate $(D C P)$. Pelat DCP juga dilengkapi dengan baut tulang (bone screw) untuk megikatkan pelat dengan struktur tulang. Metode penyembuh 
fraktur tulang menggunakan DCP juga terbukti lebih unggul bila dibandingkan dengan cara konvensional yang menggunakan bebatan kain maupun semen (gips) (Witte, 2008).

Material yang digunakan untuk baut tulang hingga saat ini umumnya adalah dari bahan tahan karat (non degradable). Walaupun penggunaan logam anti karat memiliki kelebihan karena dapat memberikan stabilitas yang maksimal (Witte, 2008). Namun secara klinis juga ditemukan beberapa kekurangannya, misalnya: kesulitan pengambilan gambar sinar- $X$ maupun MRI (magnetic resonance imaging) dan diperlukan operasi kedua untuk pengambilan baut tulang yang telah diimplan. Penggunaan bahan tahan karat juga dapat memberikan trauma kedua pada pasien dan adanya bekas lubang baut tulang, sehingga berpotensi timbulnya fraktur tulang lanjutan (Zhao, 2009). Oleh karena itu, para ahli ortopedik dan biomaterial berupaya untuk mengembangkan baut tulang yang mampu terdegradasi (degradable bone screw). Baut jenis ini dapat dengan sendirinya terdegradasi secara terukur, dimana waktu degradasinya disesuaikan dengan waktu proses penyembuhan fraktur tulang, sehingga tidak diperlukan operasi kedua kepada pasien. Saat ini, alternatif material implan mampu terdegradasi yang dapat digunakan adalah berbasis polimer maupun logam. Bila dibandingkan material berbahan logam, polimer memberi support biomekanik yang lebih rendah, sehingga bahan logam mampu terdegradasi merupakan suatu alternatif (Rimondini, 2004).

Magnesium memiliki sifat mekanik menyerupai tulang dan mampu terdegradasi, dimana produk degradasinya dapat terurai kedalam tubuh dan tidak berbahaya (non-toxic) bagi metabolisme tubuh. Magnesium dan paduannya menjadi alternatif bahan implant baut tulang yang potensial. Untuk menghasilkan baut tulang logam magnesium, diperlukan sebuah proses pengecoran khusus, karena sifatnya yang reaktif, mudah teroksidasi, dan cepat terbakar (pyrophoric).

Proses pengecoran juga merupakan teknologi produksi yang cocok untuk menghasilkan produk atau komponen yang kecil seperti baut tulang. Menurut Witte et al. (2008), proses pengecoran magnesium juga tidak mudah dilakukan karena produk cornya cenderung menghasilkan porositas makro dan mikro yang tidak homogen.

Artikel ini bertujuan mereview peluang dan tantangan aplikasi baut tulang mampu terdegradasi berbasis logam magnesium. Proses pengecoran magnesium dan paduannya untuk menghasilkan baut tulang yang memenuhi standar material ortopedik, dengan sifat biokompatibel dan mampu terdegradasi juga akan dijelaskan. Pemahaman yang baik mengenai berbagai aspek metalurgi dan proses produksi baut tulang berbasis magnesium dan paduannya, dapat memberi peluang bagi para peneliti dan praktisi industri di Indonesia untuk mampu memproduksi sendiri baut tulang, sehingga akan mengurangi ketergantungan kita terhadap produk bahan dan alat kesehatan impor.

\section{PELAT KOMPRESI DINAMIK}

Kasus-kasus trauma tulang yang menimbulkan kerusakan pada struktur tulang, sampai saat ini masih menjadi tantangan bagi para ahli bedah ortopedik modern, karena proses penyembuhannya sering mengalami ganguan atau bahkan kegagalan (Zhao, 2009). Salah satu metode fiksasi tulang yang patah adalah dengan pemasangan penyangga struktur tulang atau pelat kompresi dinamik (dynamic compression plate, DCP). Pelat DCP terdiri dari dua bagian utama, yaitu pelat berlubang dan baut tulang yang berfungsi untuk mengikatkan pelat dengan tulang. Secara teknik implannya, metoda DCP dapat dibagi dua, yaitu model internal (internal fixation) dan eksternal (external fixation). Pada model internal, pelat dan baut tulang dipasang langsung ke tulang atau posisinya berada di bawah kulit, sementara untuk model eksternal, pelat berada di luar kulit, sebagaimana dijelaskan dalam Gambar 1 di bawah ini.

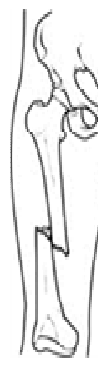

a

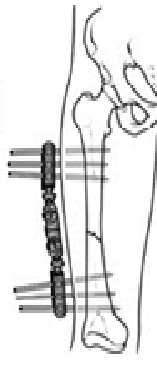

b

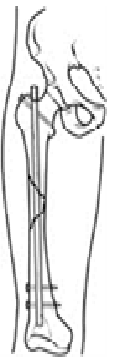

c

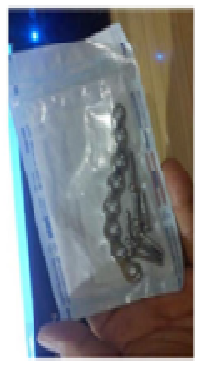

d
Gambar 1. Fraktur tulang (a); DCP dengan fiksasi eksternal (b); fiksasi internal (c); Produk pelat DCP merek Stericlin ${ }^{T M}$ buatan Jerman (d).

Secara klinis, produk DCP yang umum digunakan untuk penyembuhan fraktur tulang hinga saat ini adalah jenis pelat yang tahan karat (non degradable). Dengan adanya temuan klinis terhadap kekurangan pelat tahan karat, kini para pakar biomaterial dan kedoteran bedah ortopedik berupaya mengembangkan pelat yang mampu terdegradasi. Material baut tulang mampu terdegradasi yang sudah ada di pasaran adalah 
berbasis polymer (polymeric-based) dan logam (metallic-based).

Baut tulang berbasis polimer diantaranya adalah: PLA (poly-lactic acid), PGA (poly-glicolic acid), TMC (trimethylene carbonate), PDS (polydiaxonone), dan berbagai ko-polimer dari bahanbahan tersebut serta bahan kompositnya dengan variasi komposisi yang spesifik [Anker, 2005]. Aplikasi baut tulang berbasis polimer memiliki kelebihan dalam hal modulus yang rendah dan tahanan deformasi terhadap fase anorganik, namun aplikasinya dibatasi karena kekuatan mekanik bahan yang relatif rendah. Bahan berbasis polimer dan ko-polimernya juga umumnya hanya dapat diaplikasikan untuk kasus fraktur tulang dengan gaya tarik, gaya geser dan gaya kompresi yang relatif rendah (Wittenberg, 1991).

Keterbatasan tersebut membuka peluang aplikasi baut tulang mampu terdegradasi berbasis magnesium yang memiliki kelebihan pada sifat mekanik dan modulus elastisitasnya yang baik dan menyerupai tulang manusia. Selain itu magnesium juga termasuk unsur yang dibutuhkan untuk pertumbuhan tulang manusia dan produk degradasinya tidak berbahaya bagi tubuh. Resume perbandingan antara sifat mekanik tulang manusia dan berbagai biomaterial untuk baut tulang dipresentasikan pada Tabel 1.

Berdasarkan Tabel 1, bahan berbasis magnesium dan paduannya memiliki angka modulus elastisitas yang sangat mendekati tulang manusia, baik jenis cortial maupun cancellous bila dibandingkan dengan Ti6Al4V, maupun bahan berbasis keramik seperti hydroxyapatite (HA) dan polimer jenis PLA

Tabel.1. Perbandingan sifat mekanik polimer, logam, dan tulang manusia

\begin{tabular}{lccccc}
\hline \multicolumn{1}{c}{ Sifat Mekanik } & $\begin{array}{c}\text { Kekuatan } \\
\text { Luluh (MPa) }\end{array}$ & $\begin{array}{c}\text { Kekuatan } \\
\text { Tarik (MPa) }\end{array}$ & $\begin{array}{c}\text { Modulus } \\
\text { Elastisitas } \\
(\mathrm{GPa})\end{array}$ & $\begin{array}{c}\text { Elonga- } \\
\text { tion (\%) }\end{array}$ & Pustaka \\
\hline $\begin{array}{l}\text { Tulang Manusia } \\
\text { - Tulang cortical }\end{array}$ & $104,9-114,3$ & $35-283$ & $5-23$ & $1,1-2,0$ & Doblare, 2004; Kim, \\
- Tulang Concellous & - & $1,5-38$ & $10-1570$ & - & 2003 \\
$\begin{array}{l}\text { Material logam } \\
\text { - Magnesium }\end{array}$ & $150-220$ & 445 & 44 & 4 & Denkana, 2011; Witte, \\
- Titanium/Ti6Al4V & $760-880$ & $830-1025$ & 116 & 10 & 2008; Black, 1998 \\
- Stainless Stell/316L & $170-310$ & $480-620$ & 193 & 40 & \\
$\begin{array}{l}\text { Materia Polimer } \\
\text { - Poly(methyl }\end{array}$ & & & & & \\
$\quad$ methacrylate) & - & 30 & 28 & 1,4 & Rimondini, 2004; \\
- DL-PLA & - & $28-50$ & $1,2-3$ & 300 & Wittenberg, 1991 \\
\hline
\end{tabular}

\section{MAGNESIUM DAN PADUANNYA}

Magnesium (Mg) dan paduannya telah mendapatkan perhatian khusus dari para peneliti biomaterial dunia karena potensi aplikasinya pada berbagai bidang industri modern, termasuk bidang kedokteran tulang (orthopedic). Para peneliti material maju dunia memberikan preferensi kepada $\mathrm{Mg}$ dan paduannya karena memiliki sifat kimia-fisik dan mekanik mendekati tulang manusia, berdensitas rendah, dan biokompatibel. Contoh, modulus elastisitas $\mathrm{Mg}$ adalah 40-50 GPa, mendekati modulus elastisitas tulang manusia 10-40 GPa (Kim, 2003). Magnesium juga merupakan elemen yang penting dan diperlukan untuk proses metabolisme tubuh manusia, dan standar makanan bergizi adalah memiliki kandungan unsur magnesium sekitar 300-400mg (Gu, 2009).

Namun, magnesium dan paduannya juga memiliki kekurangan, diantaranya adalah sifat elastisitasnya rendah dan laju korosi tinggi.
Implant magnesium memiliki angka laju korosi $19-44 \mathrm{mg} / \mathrm{cm}^{2} /$ hari untuk total area muka implant seluas $9 \mathrm{~cm}^{2}$ (Song, 2007). Dalam proses degradasi ini magnesium diubah menjadi $\mathrm{Mg}^{2+}$ yang mudah diserap sistem di dalam tubuh manusia. Meskipun demikian, proses degradasi magnesium juga memiliki efek negatif karena menghasilkan gelembung hidrogen (hydrogen bubble) yang berbahaya bagi kesehatan manusia (Rimondini, 2004).

Konsep aplikasi baut tulang mampu luruh adalah kecocokan antara kecepatan korosi baut tulang dan proses penyembuhan fraktur tulang. Dimana, pada saat proses penyambungan fraktur tulang telah sempurna, maka di saat bersamaan baut tulang telah terdegradasi penuh, sehingga tidak diperlukan proses operasi kedua untuk pengangkatan baut tulang.

Untuk mengurangi kelemahan aplikasi magnesium, para pakar material dunia berusaha mencari berbagai jenis komposit yang optimum 
untuk meningkatkan kekuatan tarik, elastisitas bahan, dan perbaikan sifat mekanik lain, misalnya dengan penambahan unsur paduan, seperti: Aluminum (Al), Perak (Ag), Silikon (Si), Timah (Sn), Seng (Zn), dan Zirkonium (Zr) (Denkana, 2011). Selain itu, untuk mengurangi laju korosi magnesium yang tinggi, ada beberapa unsur paduan yang umum ditambahkan, seperti: Cadmium (Cd), manganase (Mn), dan Calsium (Ca) (Fan, 2005).

Berikut adalah pengaruh unsur paduan utama terhadap sifat logam magnesium: Aluminum (Al) meningkatkan mampu cor dan elastisitas paduan; Mangan (Mn) meningkatkan sifat ulet; Kalsium (Ca) untuk penguatan presipitasi dan peningkatan mampu mulur; dan Lithium (Li) adalah satu-satunya unsur yang dapat mengubah struktur kristal magnesium dari heksagonal tumpukan-padat (HCP) menjadi kubus pusat muka (BCC) dipaduan magnesium. Paduan magnesium dengan struktur kristal BCC memiliki sifat mampu cor yang lebih baik, meskipun kekuatan tariknya lebih rendah dibandingkan HCP (Luo, 2013).

\section{PENGECORAN MAGNESIUM UNTUK APLIKASI BAUT TULANG}

Sistem pengecoran magnesium dapat dilakukan melalui dua metode, yaitu: pengecoran cair dan sintering logam serbuk. Berikut adalah penjelasan mengenai kedua metode produki magnesium tersebut. Sistem pengecoran cair adalah melalui proses penuangan logam cair ke dalam cetakan yang memiliki rongga sesuai dengan dimensi dan bentuk yang dirancang.
Karena sifat magnesium yang reaktif, maka dalam pengecoran cair umumnya digunakan fluks atau gas pelindung, seperti: Argon (Ar) dan Sulfur hexafluoride $\left(\mathrm{SF}_{6}\right)$. Pengecoran cair dapat dilakukan menggunakan beberapa teknik, diantaranya: pengecoran tekan (die-casting), dan pengecoran tekanan tinggi (squeeze casting).

Proses pengecoran tekan umumnya menggunakan pompa hidrolik dengan tekanan antara 80 s.d. 40.000 Psi. Berdasarkan temperatur prosesnya jenis pengecoran ini dibagi dua, yaitu pengecoran tekan ruang panas (hot chamber die-casting) dan ruang dingin (cold chamber die-casting) (Gambar 2). Pengecoran tekan ruang panas tepat untuk magnesium, karena kontak antara logam cair dan udara sangat kecil sehingga mengurangi potensi oksidasi logam (Luo, 2013).

Dalam proses pengecoran ruang panas, leher saluran berada di ruang pencairan logam dan plunger akan memompa cairan logam menuju ruang cetak. Selanjutnya, dalam pengecoran ruang dingin, proses pencairan logam tidak berada di dalam mesin cor dan logam cair dituangkan ke dalam saluran dan kemudian dipompa oleh plunger untuk masuk ke dalam ruang cetak.

Untuk proses pengecoran tekanan tinggi (squeeze casting), logam cair ditekan ke dalam cetakan dengan tekanan yang relative lebih besar bila dibandingkan kedua proses di atas. Karena tekanan yang besar tersebut, maka proses transfer logam cair menuju ruang cetak (die) hanya memerlukan waktu yang sangat
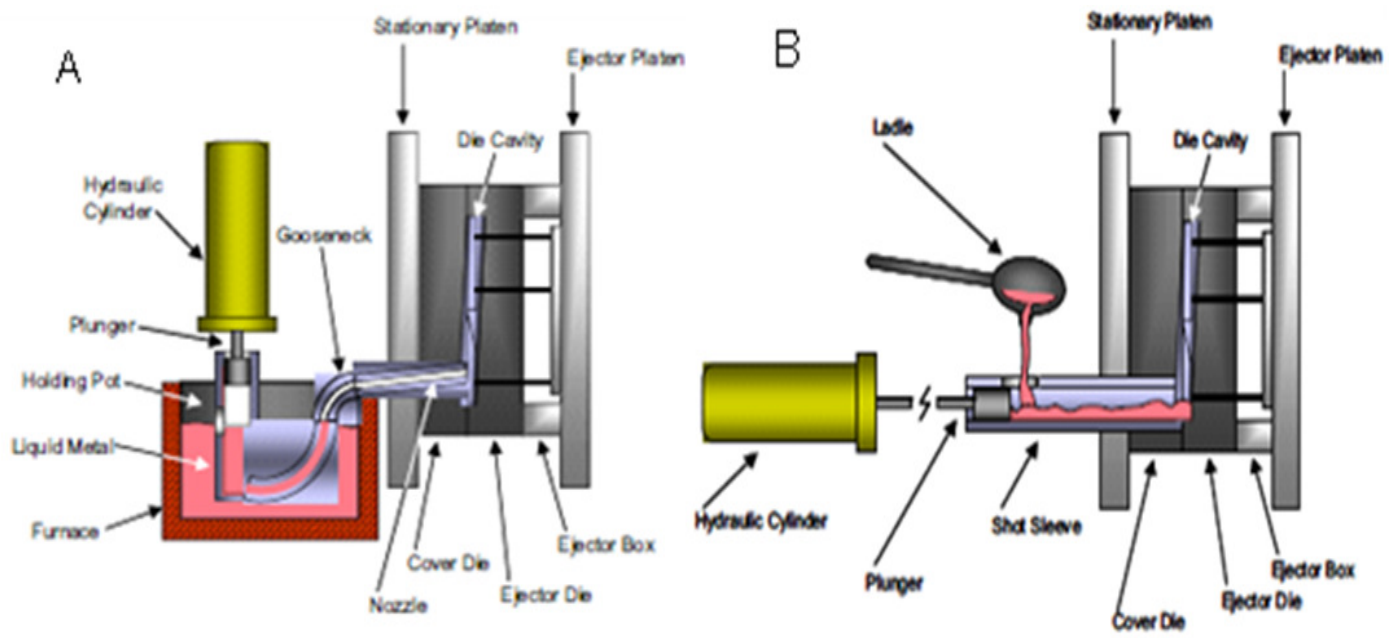

Gambar 2. Skema pengecoran tekan ruang panas (a), dan ruang dingin (b) (Luo, 2013) 
singkat, sehingga dapat menghasilkan permukaan logam magnesium yang lebih halus dan dengan porositas yang sangat sedikit ( $\mathrm{Hu}$, 1998).

\section{TEKNIK METALURGI SERBUK}

Dalam proses logam serbuk, mula-mula dicampurkan bahan baku logam berupa serbuk dengan ukuran (mesh) tertentu, dan diaduk agar terjadi pencampuran serbuk logam dicampur secara homogen. Kondisi pencampuran sebagian besar tergantung pada perbedaan kepadatan antara bahan utama dari campuran bubuk setelah tercampur dilakukan proses sintering. Sintering dilakukan untuk meningkatkan ikatan antara serbuk sehingga meminimalkan porositas (Gupta, 2000).

Microwave juga merupakan salah satu alternatif alat yang bisa digunakan untuk proses sintering serbuk magnesium, dimana panas dihasilkan dari gelombang mikro, dimana gelombang elektrik dan gelombang magnetik bersama-sama melakukan sintering. Sifat yang diinginkan dari bahan dapat dicapai melalui sintering microwave karena (a) waktu sintering lebih pendek dan (b) suhu sintering rendah (Gupta, 2000 dan Luo, 2013).

Berbeda dengan proses sintering tradisional, pada microwave pemanasan terjadi dari dalam ke luar serbuk secara bersamaan sehingga dihasilkan karakteristik mikrostruktur yang rendah pada permukaannya (Nguyen, 2008). Cara kerja sintering dalam proses ini adalah dari panas yang bersumber dari oven (microwave) dan panas yang terjebak di dalam ruang vakum (microwave-coupled) atau dikenal dengan efek pemanasan dua arah (two-way heat system), dipopulerkan oleh Gupta (2000) dan Meenashisundaram (2014).

\section{KESIMPULAN}

Baut tulang mampu terdegradasi memiliki potensi yang besar untuk dapat diaplikasikan di masa datang, dimana dapat berbasis polimer maupun magnesium. Baut tulang berbahan magnesium dapat memberikan dukungan biomekanis yang lebih besar bila dibandingkan polimer. Namun sifat reaktif dan waktu degradasi magnesium dan paduannya yang cepat masih merupakan tantangan utama untuk aplikasi ini. Strategi komposit dengan penambahan unsurunsur yang dapat meningkatkan ketahanan korosi, maupun sistem pengecoran maju telah diaplikasikan dalam upayakan memproduksi baut tulang berbasis logam magnesium. Teknik sintering logam serbuk menggunakan microwave yang memanfaatkan panas yang dihasilkan dari gelombang mikro merupakan teknik terkini yang memiliki peluang besar dalam memproduksi baut tulang magnesium.

\section{UCAPAN TERIMA KASIH}

Penulis mengucapkan terima kasih kepada Kemenristekdikti atas dukungan finansialnya melalui Hibah Kompetensi tahun 2016, No.: 78/UN26/8/LPPM/2016.

\section{DAFTAR PUSTAKA}

Anker C. J., Holdridge S. P., 2005, Ultraporous beta-tricalcium phosphate is well incorporated in small cavitary defects, Clin. Orthop. Relat. Res. 434, 251-257

Black J., 1998, Orthopaedic Biomaterials in Research and Practice, New York: Churchill Livingstone

Doblare M., 2004, Modelling bone tissue fracture and healing: a review, Engineering Fracture Mechanics 71, 1809-1840.

Denkana A., Thorey F., Waizy H., Angrisani N., Lindenberg A. M., 2011, Biocompatible Magnesium Alloys as Dagradable Implant Material - Machining Induced Surface and Subsurface Properties and Implant Permormance, Spesial Issue on Magnesium Alloys, 109-128.

Fan Z., 2005, Development of the rheodiecasting process for magnesium alloys. Mater. Sci. Eng. A 413, 72-78.

Gu X., Zheng Y., Cheng Y., 2009, In vitro corrosion and biocompatibility of binary magnesium alloys, Biomaterials 30(4), 484498.

Gupta M., Lai M., Saravanaranganathan D., 2000, Synthesis, microstructure and properties characterization of dis-integrated melt deposited $\mathrm{Mg} / \mathrm{SiC}$ composites, J. Mater. Sci. 35, 2155-2165.

Hu B. H., 1998, Squeeze Casting of Al-Si-Cu- FeMn-Mg Alloy, Journal of Processing and Fabrication of Adv. Mater. VI vol. 1.

Kim S. R., Lee J. H., Kim Y. T., Rui D. H., Jung S. J., Lee Y. J., Chung S. C., Kim Y. H., 2003, Synthesis of $\mathrm{Si}, \mathrm{Mg}$ substituted hydroxypatatite and their sintering behaviors, Biomaterials 24, 1389- 1398 .

Luo A., 2013, Magnesium casting technology for structural applications, Journal of Magnesium and Alloys 1, 2-22.

Meenashisundaram G. K., Sankaranarayanan S., Gupta M., 2014, Enhancing overall tensile and compressive response of pure Mg using nano-TiB2 particulates, Mater. Charact. 94, 178-188.

Nguyen Q., Gupta M., 2008, Enhancing compressive response of AZ31B 
magnesium alloy using alumina nanoparticulates, Compos. Sci. Technol. 68, 2185-2192

Reksoprawiro S., 2006, Bedah Kepala Leher XI, Penggunaan Miniplate pada Penatalaksanaan Fraktur Maxilofacial, Farmacia, Vol.7 No.1, 56-57.

Rimondini L., Nicolo N. A., Milena F., Gaetano G., Matilde T., Giordino R., 2004, In Vivo Experemental Study on Bone Regeneration in Critical Bone Defects using An Injectable Biodagradable PLA/PGA Copolymer, Oral Surgery, Bologna Instituti Orthopedic Giardino

Song G., 2007, Control of Biodegradation of biocompatible magnesium alloys, Corros. Sci. 49, 1696-1701.

Witte F., Hort N., Vogt C., 2008, Degradable biomaterials based on magnesium corrosion, Current Opinion in Solid State and Materials Science, 12(5-6), 63-72.

Wittenberg J. M., Wittenberg R. H., 1991, Biomechanical properties of resorbable poly-Llactide plates and screws: a comparison with traditional systems, J. Oral Maxillofac. Surg. 49, 512-516.

Zhao J.; Zhiyuan Z., Shaoyi W., Xiaojuan S., Xiuli Z., Chen J., Kaplan D., Jiang X., 2009, Apatite-Coated Silk Fiboin Scaffolds to Heating Mandibular Border Defect in Canines, Bone 45, 517-527. 